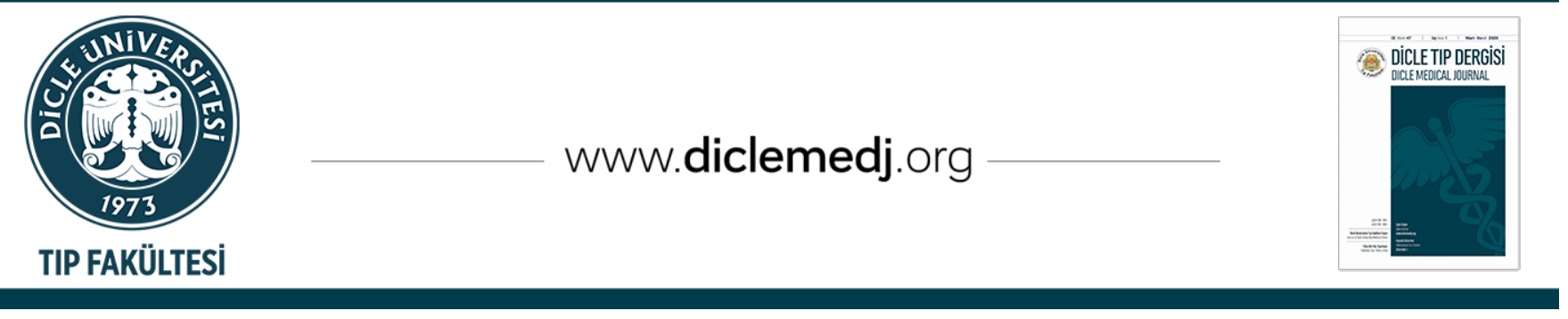

Original Article / Özgün Araştırma

\title{
Parkinson's Disease Profile - A 17-Year Patient Analysis
}

\author{
Ahmet Adiguzel ${ }^{i D_{1}}$, Unal Ozturk ${ }^{D_{2}}$, Sibel Altinayar ${ }^{D_{3}}$ \\ 1 Department of Neurology, University of Health Sciences, Diyarbakir Gazi Yasargil Education and Research Hospital, Diyarbakır, Turkey \\ 2 Department of Neurology, University of Health Sciences, Diyarbakir Gazi Yasargil Education and Research Hospital, Diyarbakır, Turkey
}

3 Department of Neurology, Inonu University, Faculty of Medicine, Malatya, Turkey

Received: 31.03.2020; Revised: 10.06.2020; Accepted: 23.06.2020

\begin{abstract}
Objective: Idiopathic Parkinson's disease (IPD) is a progressive degenerative disease, which increases over the age of 65 years and causes disability in advanced stages. The main pathology is the degeneration of the basal ganglia, especially the substantia nigra. In the clinic, motor and non-motor findings (NMF) are seen, and treatment approach is symptomatic. Factors that increase the risk in Parkinson's disease are male gender, old age, white race, environmental conditions, trauma, vascular diseases, family history, and genetic mutations. In this study, idiopathic Parkinson's patients who came to our movement disorders outpatient clinic in the last 17 years were evaluated retrospectively. We aimed to determine the IPD profile in our region through demographic and clinical findings and treatments used and compare the results with the literature.
\end{abstract}

Methods: We evaluated 1150 patients admitted to the neurology department of movement disorders outpatient clinic due to parkinsonism. Five hundred seventy-eight patients with IPD were included in the study.

Demographic data such as age, sex, place of birth, place of residence (rural/urban), comorbidities, family history, and habits were recorded.

Results: A total of $63.5 \%$ of the patients were male. The mean age of the patients was 68.51 (SD \pm 10.35 ) years old for males and $68.37(\mathrm{SD} \pm 11.22$ ) years old for females, $62.61(\mathrm{SD} \pm 11.31$ ) for males and $62.55(\mathrm{SD} \pm 12.46$ ) for females. 66.4\% of the patients had the first clinical finding as tremor, while $55.4 \%$ had the tremor as the leading complaint. It was seen that $57 \%$ of the patients had NMF. It was observed that $52.8 \%$ of the patients did not have dementia. As the clinical stage progressed, it was determined that there was a significant increase in dementia rate. Hypertension (HT) (M/F\%:35,2/47,2 p=0.01) and thyroid diseases $(M / F \%: 2.3 / 10.3 p=0,00)$ were more frequent in female patients than in male patients. Impulsive-compulsive behaviors (ICBs) which are treatment-related problems were more common in males than in females (M/F\%:17.8/8.5 p=0,00).

Conclusion: The results were found to be similar to the literature. In this study, we have noticed the neglected, incomplete, or inadequately questioned parameters in routine-intensive outpatient conditions. Taking these results into consideration, we had the opportunity to correct our shortcomings in our future studies.

Keywords: Tremor, Bradykinesia, Idiopathic Parkinson's disease

DOI: $10.5798 /$ dicletip.757233

Correspondence / Yazışma Adresi: Unal Ozturk, Department of Neurology University of Health Sciences, Diyarbakır Gazi Yasargil Education and Research Hospital Uckuyular, Kayapinar, Diyarbakir, Turkey e-mail drunalozturk@gmail.com 


\section{Parkinson Hastalığı - 17 Yıllık Hasta Analizi}

$\ddot{0} \mathbf{z}$

Giriș: İdiopatik Parkinson Hastalı̆̆ı (IPH) progresif dejeneratif bir hastalıktır. Altmıș beş yaş üstünde görülme sıklığı artar ve ileri evrelerde özürlülüğe neden olur. Temel patoloji subtantia nigra (SN) bașta olmak üzere bazal ganglion dejenerasyonudur. Kliniğinde motor ve non-motor bulgular (NMB) görülür, tedavi yaklaşımı semptomatiktir. Parkinson hastalığında erkek cinsiyet, ileri yaş, beyaz ırk, çevresel etmenler, travma, vasküler hastalıklar, aile öyküsü, genetik mutasyonlar gibi riski artıran durumlar vardır. Bu çalışmada son 17 yılda Hareket Bozuklukları polikliniğimize gelen İdiopatik Parkinson hastalarını retrospektif olarak değerlendirdik. Hastaların demografik ve klinik bulgularını, kullanılan tedavileri inceleyerek bölgemizdeki IPH profilini oluşturmayı ve çıkan sonuçları literatürle karşılaştırmayı amaçladık.

Yöntemler: Bu amaçla, Nöroloji bölümü hareket hastalıkları polikliniğine parkinsonizm nedeniyle başvuran 1150 hasta değerlendirildi. Bunlardan IPH tanısı olan 578 hasta çalışmaya alındı. Hastaların yaş, cinsiyet, doğum yeri, yaşadığı yerleşim yeri (kırsal-kentsel), eşlik eden hastalıklar, soygeçmişleri, alışkanlıkları gibi demografik verileri kaydedildi. Klinik olarak; hastalığın başlangıç yaşı, ilk klinik bulgu, baskın olan semptom, non-motor bulgu, tedavi ve tedaviye bağlı gelişen sorunlar kaydedildi.

Bulgular: Hastaların \%63,5 i erkekti. Hastaların yaş ortalaması erkeklerde 68.51 (SD \pm 10.35), kadınlarda 68.37 (SD \pm 11.22), hastalığın başlangıç yaşı erkeklerde 62.61 (SD \pm 11.31 ), kadınlarda 62.55 (SD \pm 12.46 ) idi. Tremor, hastaların \%66,4 ünde ilk klinik bulgu iken \%55.4 ünde de önde gelen yakınma olarak tespit edildi. Hastaların \%57 sinde NMB olduğu görüldü. Hastaların \%52,8 inde demans olmadığı görüldü. Klinik evre ilerledikçe demans oranında belirgin artış olduğu tespit edildi. Hipertansiyon (HT) (E/K\%:35,2/47,2 p=0.01) ve tiroid hastalıkları ( $\mathrm{E} / \mathrm{K} \%: 2.3 / 10.3 \mathrm{p}=0,00)$ kadın hastaların özgeçmişlerinde erkeklere oranla daha fazla görüldü. Tedaviye bağlı sorunlardan impulsif-kompulsif davranışlar (IKD) erkeklerde daha fazla görüldü ( $\mathrm{E} / \mathrm{K} \%: 17.8 / 8.5 \mathrm{p}=0,00)$.

Sonuç: Değerlendirilen parametrelerin sonuçları literatürle büyük oranda benzer bulundu. Bu çalışma ile rutin-yoğun poliklinik koşullarında ihmal edilen, eksik veya yetersiz sorgulanan parametrelerin de farkına varmış olduk. Bu sonuçları dikkate alarak, bundan sonraki çalışmalarımızda eksiklerimizi düzeltme fırsatını yakaladık.

Anahtar kelimeler: Tremor, Bradikinezi, İdiopatik Parkinson Hastalığı.

\section{INTRODUCTION}

Idiopathic Parkinson's disease (IPD) is the second most common neurodegenerative disease after Alzheimer's disease (AD), affecting approximately $2 \%$ of people 65 years of age and above and $4-5 \%$ of those 85 years of age ${ }^{1}$. It is characterized by extrapyramidal system involvement. Histopathologically, the substantia nigra pars compacta contains the loss of dopaminergic neurons and Lewy bodies (LC), which are eosinophilic, intracytoplasmic proteinous inclusion bodies ${ }^{2}$. Motor findings usually begin with single limb involvement. There are four cardinal signs of Parkinson's disease. These include rest tremor, rigidity, bradykinesia, and postural instability. This disease is more common in men, and the risk increases two to three times in individuals with a family history of IPD ${ }^{3-4}$. Environmental factors such as heavy metal, 1-methyl-4-phenyl-1,2,3,6tetrahydropyridine (MPTP), and pesticide exposure; well water consumption; and carbon dioxide intoxication increase the risk of developing the disease ${ }^{5}$. Recent studies suggest that smoking and coffee have protective effects $^{6}$. Although there are many pharmacological agents and surgical methods as treatment, the most effective agent is levodopa7.

In our center located in the Eastern Anatolia region, the movement disorders outpatient clinic has been regularly maintained for nearly 20 years. In this study, we aimed to analyze the demographic and clinical data of our patients who were followed up in our outpatient clinic retrospectively, to compare with the literature, and to determine the differences, if any, in our region. 


\section{METHODS}

The study was approved by the Inonu Medical Faculty Ethics Committee. Ethics committee approval was obtained for this protocol 2017/13-15 on $20 / 06 / 2017$. Informed consent was obtained. The study complied with the Declaration of Helsinki.

This study included patients with IPD who were followed up at the Movement Disorders Policlinic of the Neurology Department of Inonu Medical Faculty between January 1, 2000 and January 1, 2017. For this purpose, 1150 patients who presented with parkinsonism were evaluated retrospectively.

Patients 18 years old and above with IPD were included in the study. Patients diagnosed with IPD with outpatient follow-up less than three times and who did not have sufficient information in the file and patients with secondary parkinsonism and Parkinson-plus syndrome were excluded. Accordingly, 578 patients who met the research criteria were included in the study. Age, gender, place of birth, characteristics of the settlement (village, town, city), resume and family history, habits, and characteristics related to the disease (age of onset, duration of disease, stage, premorbid pain, signs and symptoms, treatment, NMF, on-off period, end-dose worsening, ICB, presence of dystonia, and dyskinesias) were recorded.

\section{Statistical Analysis}

SPSS Version 17 program was used for statistical analysis, and Pearson's chi-squared test was used for data analysis. Significance level was accepted as $\mathrm{p} \leq 0.05$ in all tests. The stage of IPD was determined by the Modified Hoehn and Yahr Staging Scale (H\&Y).

\section{RESULTS}

Of these patients, 367 (63.5\%) were male, and 211 (36.5\%) were female. There was no statistical difference between the mean age of the male and female patients and the age at onset of the disease $(p=0,320)$. Malatya was the birth place of $69 \%$ of the patients who participated in our study. According to the information obtained from the patients, the settlement where they lived in the last 5 years is shown in Figure 1.

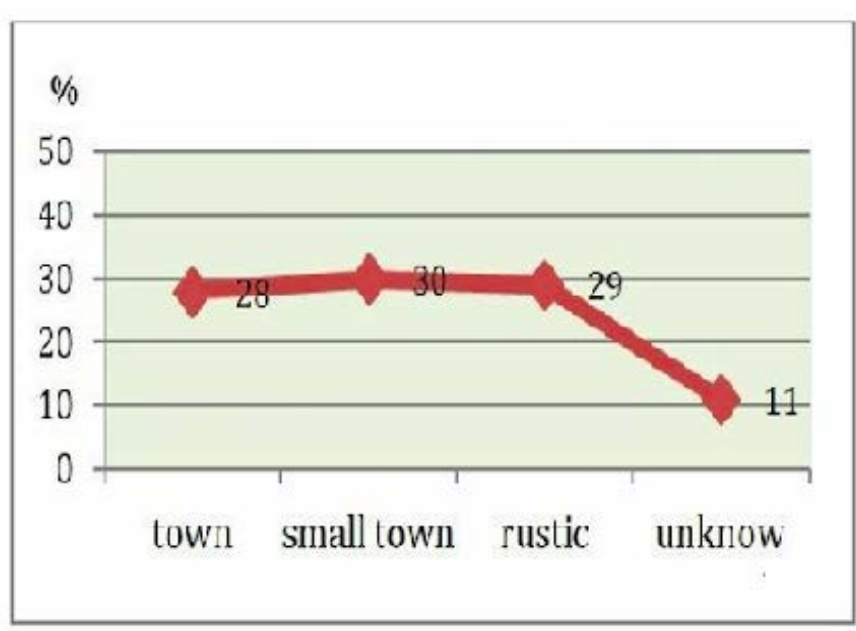

Figure 1. Settlement where they lived in

Tremor was the most common clinical and most dominant symptom that disturbed the patient. The mean stage of the patients according to the H\&Y was 2.4. These demographic results are summarized in Table 1.

Table I: Demographic features

\begin{tabular}{|l|l|l|l|}
\hline & Male & Female & Total \\
\hline $\begin{array}{l}\text { Number of patients: n } \\
(\%)\end{array}$ & $367(63.5 \%)$ & $211(36.5 \%)$ & 578 \\
\hline $\begin{array}{l}\text { Average of the age, SD } \\
\text { (year) } \\
\text { min-max. age }\end{array}$ & $68.51, \pm 10.3$ & $68.37, \pm 11.2$ & $68.46 \pm 10.6$ \\
\hline $\begin{array}{l}\text { Age of Onset of } \\
\text { Disease, SD (year) } \\
\text { min-max age }\end{array}$ & $62.61, \pm 11.3$ & $62.55, \pm 12.4$ & $62.6 \pm 11.7$ \\
\hline First Sign of Disease & $15-92$ & $13-96$ & $13-96$ \\
Tremor n, (\%) & $235-(40.6 \%)$ & $149(25.8 \%)$ & $384(66,4 \%)$ \\
Bradykinesia n, (\%) \\
other n, (\%)
\end{tabular}


Table II: Clinical features

\begin{tabular}{|c|c|c|c|c|c|c|c|}
\hline & Male & & Female & & Total & & $p$ \\
\hline Non-motor symptoms & $\begin{array}{l}\text { Yes } \\
n(\%)\end{array}$ & $\begin{array}{l}\text { No } \\
\text { n(\%) }\end{array}$ & $\begin{array}{l}\text { Yes } \\
\text { n(\%) }\end{array}$ & $\begin{array}{l}\text { No } \\
\text { n(\%) }\end{array}$ & $\begin{array}{l}\text { Yes } \\
\text { n(\%) }\end{array}$ & $\begin{array}{l}\text { No } \\
\text { n(\%) }\end{array}$ & \\
\hline $\begin{array}{l}\text { Depression } \\
\text { Constipastion } \\
\text { RBD } \\
\text { Hyposmia } \\
\text { Pain } \\
\text { Demantia }\end{array}$ & $\begin{array}{l}67(23,8) \\
124(44,4) \\
149(51,9) \\
27(10,3) \\
74(27,5) \\
137(42,8)\end{array}$ & $\begin{array}{l}214(76,2) \\
155(55,6) \\
138(48,1) \\
234(89,7) \\
194(72,5) \\
183(57,2)\end{array}$ & $\begin{array}{l}44(28,6) \\
85(54,1) \\
83(50,9) \\
19(12,7) \\
59(39,1) \\
70(36,5)\end{array}$ & $\begin{array}{l}110(71,4) \\
72(45,9) \\
80(49,1) \\
131(87,3) \\
92(60,9) \\
122(63,5)\end{array}$ & $\begin{array}{l}111(25,5) \\
209(47,9) \\
232(51,6) \\
46(11,2) \\
133(31,7) \\
207(40,4)\end{array}$ & $\begin{array}{l}324(74,5) \\
227(52,1) \\
218(48,4) \\
265(88,8) \\
286(68,3) \\
305(59,6)\end{array}$ & $\begin{array}{l}0,16 \\
0,03^{*} \\
0,45 \\
0,28 \\
0,01 * \\
0,49\end{array}$ \\
\hline $\begin{array}{l}\text { Background } \\
\text { Hypertension (HT) } \\
\text { Cardiac diseases (excluding HT) } \\
\text { Thyroid diseases } \\
\text { Diabetes mellitus (type 2) } \\
\text { Other diseases }\end{array}$ & $\begin{array}{l}92(35,7) \\
75(30,2) \\
6(2,3) \\
50(18,9) \\
141(53,6)\end{array}$ & $\begin{array}{l}166(64,3) \\
178(69,8) \\
250(97,7) \\
214(81,1) \\
122(46,4)\end{array}$ & $\begin{array}{l}75(47,2) \\
45(47,2) \\
16^{\star}(10,3) \\
27(16,9) \\
79(49,4)\end{array}$ & $\begin{array}{l}84(52,8) \\
112(52,8) \\
140(89,7) \\
133(83,1) \\
81(50,6)\end{array}$ & $\begin{array}{l}167(38,1) \\
120(29,6) \\
22(5,3) \\
77(18,2) \\
220(52)\end{array}$ & $\begin{array}{l}250(61,9) \\
290(70,4) \\
390(94,7) \\
347(81,8) \\
203(48)\end{array}$ & $\begin{array}{l}0,01 * \\
0,41 \\
0,00^{*} \\
0,34 \\
0,22\end{array}$ \\
\hline Smoking & $61(41,2)$ & $87(58,8)$ & $7(5,2)$ & $127(94,8)$ & $68(24,1)$ & $214(74,9)$ & $0,00^{*}$ \\
\hline $\begin{array}{l}\text { Treatment } \\
\text { Levodopa } \\
\text { Dopamine agonists } \\
\text { MAO-B inh. }\end{array}$ & $\begin{array}{l}314(85,8) \\
236(64,7) \\
224(61,7)\end{array}$ & $\begin{array}{l}52(14,2) \\
129(34,3) \\
142(38,8)\end{array}$ & $\begin{array}{l}174(83,3) \\
130(61,9) \\
117(56)\end{array}$ & $\begin{array}{l}35(16,7) \\
80(38,1) \\
92(44)\end{array}$ & $\begin{array}{l}488(84,9) \\
366(63,7) \\
341(59,3)\end{array}$ & $\begin{array}{l}87(15,1) \\
209(36,3) \\
234(40,7)\end{array}$ & $\begin{array}{l}0,42 \\
0,28 \\
0,12\end{array}$ \\
\hline $\begin{array}{l}\text { Treatment problems } \\
\text { ICBs } \\
\text { DSE } \\
\text { Wearing-off } \\
\text { On-off } \\
\text { Dystonia } \\
\text { Dyskinesia }\end{array}$ & $\begin{array}{l}48(17,8) \\
169(53,5) \\
55(17,8) \\
60(20,1) \\
21(5,7) \\
93(31,5)\end{array}$ & $\begin{array}{l}221(82,2) \\
147(46,5) \\
254(82,2) \\
239(79,9) \\
346(94,3) \\
203(68,5)\end{array}$ & $\begin{array}{l}14(8,5) \\
92(50,5) \\
29(16,4) \\
29(17,2) \\
13(6,2) \\
57(35,7)\end{array}$ & $\begin{array}{l}151(91,5) \\
90(49,5) \\
148(83,6) \\
140(82,8) \\
198(93,8) \\
103(64,3)\end{array}$ & $\begin{array}{l}62(14,3) \\
261(52,4) \\
84(17,3) \\
89(19) \\
34(5,9) \\
150(32,9)\end{array}$ & $\begin{array}{l}272(85,7) \\
237(47,6) \\
402(82,7) \\
379(81) \\
544(94,1) \\
306(67,1)\end{array}$ & $\begin{array}{l}0,00 * \\
0,29 \\
0,39 \\
0,26 \\
0,48 \\
0,78\end{array}$ \\
\hline
\end{tabular}

At least one NMF was found in $57 \%$ of the cases. The most common REM sleep behavior disorder (RBD) from NMF was observed in $40.1 \%$ of the patients. Based on the frequency of distribution of other findings, constipation was found to be $36.2 \%$; pain was found to be $23 \%$; depression was found to be $19 \%$; and hyposmia was found to be $8 \%$.
When we examined the cognitive status of the patients, it was observed that more than half (52.8\%) had no dementia findings. Mild dementia was detected in $14 \%$, mild to moderate dementia in $15.1 \%$, moderate dementia in $5.4 \%$, and moderate to severe dementia in $1.4 \%$. Adequate information 
about the cognitive status of $11.4 \%$ of the patients was not available.

Among the antiparkinson drugs used by the patients, we found that levodopa was the most commonly preferred agent at $84.4 \%$.

Disease background of the patients was categorized into the following five groups: hypertension; cardiac diseases (except HT); diabetes mellitus (DM); thyroid diseases; and other diseases (asthma, benign prostatic hypertrophy, liver diseases, malignancy, and epilepsy).

When the patients were evaluated for dementia in the clinical stage of the disease, it was found that as the clinical stage progressed, the frequency of dementia statistically increased and the rate of dementia in H\&Y Stage 5 was $75 \%$.

When the habits of the patients were examined by gender, smoking was observed to be significantly higher in male patients than in female patients. Table 2 shows all clinical data in detail.

We evaluated the treatment problems related to antiparkinson drugs used in the six groups. Due to dopaminergic treatment, side effects such as nausea and vomiting; hypotension; hot flashes; and dizziness were noted in $45.2 \%$ of the patients, which were the most common problems. Impulsivecompulsive behaviors (ICBs) were seen in $10.7 \%$ of the patients. ICBs considered as; Dopamine dysregulation syndrome (DDS), punding and impulse-control disorder (ICD). Wearing-off phenomena were detected in $14.5 \%$, on-off phenomena in $15.4 \%$, dystonia in $5.9 \%$, and dyskinesia in $26.0 \%$. When we subdivided dyskinesia from treatment problems, we found peak dose in $5.7 \%$, end dose in $10.4 \%$, diphase in $13 \%$, and continuous dyskinesia in $7.6 \%$. Dopamine side effects (DSE) and on-off phenomena were significantly higher in patients with dementia. When problems related to treatment and gender were examined, it was observed that ICBs was higher in males than females. This result was statistically significant.

When we evaluated at the relationship between dementia and RBD in these patients, RBD was not seen in 142 of 240 patients without dementia $(p=0.00)$. In this way, we find that the risk of RBD increases in patients with dementia.

\section{DISCUSSION}

\section{Epidemiological and Demographic Characteristics}

In all studies conducted worldwide, age has been shown to be the most important risk factor of the disease in all populations ${ }^{8}$. Studies around the world have yielded similar results for age. Driver JA et al. reported that IPD affects $1 \%-2 \%$ of those over 65 years of age and $4 \%-5 \%$ of people over 85 years of age ${ }^{9}$. In another study published in 2014 , it was shown that prevalence and incidence increased almost exponentially with age and peaked at age 80 and above ${ }^{10}$. In our study, we found that the mean age of patients of both genders was 68 years old, and the mean age of disease onset was approximately 62 years old. In addition, when we examine the age distribution of patients, it can be seen that the peak was between 75 and 85 years old (Figure 2). This result shows that the incidence of IPD in our population has increased significantly in older ages and is similar to the global distribution.

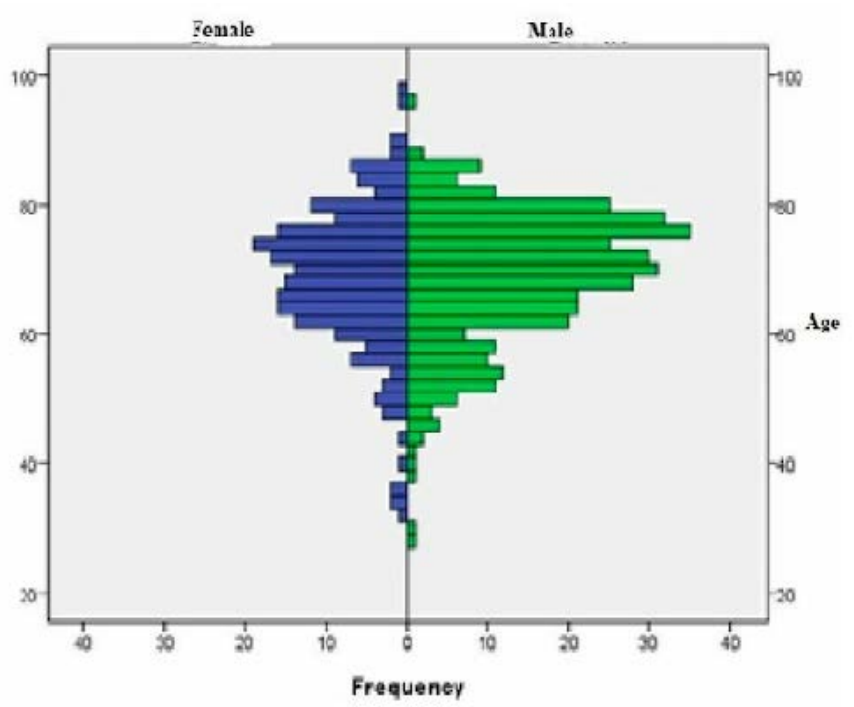

Figure 2. Age distribution

According to the studies, another known risk factor is gender. In a study conducted with 5278 people 65 years old and above in three different regions of Spain, the male-to-female (M/F) ratio of IPD patients was found to be approximately $3 / 2^{11}$. In another study conducted in Italy with 17 studies and over 2500 cases, the risk of IPD was higher in men than in women, $\mathrm{M} / \mathrm{F}$ ratio found $1.46^{12}$. In our study, 
we found that the risk was 1.73 times higher in favor of men.

Another risk factor is living in rural areas. Pesticide exposure and well water consumption are more common in rural areas. Therefore, it is suggested that IPD is seen more in rural areas. In a review of environmental risk factors published in 2016, well water use and life in rural areas were considered as potential risk factors ${ }^{5}$. In a comprehensive metaanalysis including 178 studies published in 2012, it was also shown that living in rural areas is a risk factor ${ }^{13}$. Among the patients in our region, $29.9 \%$ was the rate for those living in rural areas, $28.2 \%$ for those living in the city center, and $30.8 \%$ for those living in the town. The fact that these three ratios are very close to one another contradicts the literature. This shows that our province is the largest province in the region, which has recently become a metropolitan municipality and has escalating terror incidents in the southeast. In recent years, large migration from rural areas has occurred. Although our questions were based on the location of the patients in the last 5 years, as in other degenerative diseases, IPD probably starts much earlier neuropathologically. In our study, before the onset of the disease, we believe that the number of people living in the rural environment is much higher than what is seen. However, in order to confirm this speculative thought, we think that we should question our patients retrospectively for more than 5 years. In addition, the large population that settled in the city center through migration still maintains its relationship with the rural area and often returns to their village for agricultural activities. This was thought to be another factor affecting our outcome.

\section{Clinical Features}

IPD is divided into two main groups as tremor dominant and non-tremor dominant (bradykinesia dominant). Tremor starts asymmetrically mostly from the extremities and may not be seen in all patients. In a clinical trail published in 2016, that involved 210 patients, it has been reported that $70 \%$ of patients have tremor in the early stage of the disease $^{14}$ In another study that involved 100 patients diagnosed with IPD, it was seen that $85 \%$ of the patients developed tremor during the disease process ${ }^{15}$. Similarly in our study, we found that the first clinical finding was tremor in $66.4 \%$. The most common complaint was tremor (tremor, 55.4\%; bradykinesia, $44.6 \%$ ).

NMF seen in IPD may occur before motor findings, and new NMF may develop during the disease progression. Nonmotor findings may not be seen in every patient at the same time and create a clinic of different severity in each patient. Pain has been mentioned as a nonmotor finding in many studies. In a study of 176 patients in 2009, 146 (83\%) patients complained of pain ${ }^{16}$. A study in Turkey in 2011 involving 96 patients revealed that pain was present 63 patients $(64.9 \%)^{17}$. In our study, the incidence of pain was found to be $23 \%$. Although there are differences in the literature, it can be seen that less patients complained of pain in our study compared to that in the literature. The reason for this may be the acceptance of pain in our society at an advanced age and whether it is considered to be unrelated to Parkinson's disease or not being able to question NMFs adequately in the outpatient conditions. RBD may occur as premotor or NMF during the disease process. In our study, $40.1 \%$ of the patients had RBD during the disease process. A review published in 2006 stated that RBD was seen in about half of the patients during the illness. In another study that involved 150 patients in Japan in 2009, RBD was detected in 81 (54\%) patients as NMF18. In a prospective study in the USA in 2015, it was found that $50 \%$ of patients with RBD showed signs of parkinsonism within 10 years ${ }^{19}$. In one study, it was reported that olfactory disorders were generally seen before motor symptoms and affected approximately $90 \%$ of all Parkinson's patients with different severity ${ }^{20}$. In another study, it was found that people with hyposmia had a $10 \%$ increased risk of disease in 2 years compared with their asymptomatic counterparts 20,21 . In a study conducted in Malatya in 2014, 41 IPH butanol threshold test and odor discrimination test were evaluated, and it was observed that patients failed to distinguish odor but did not fail odor threshold test 22 . In our study, only $8 \%$ of the patients complained of hyposmia. One of the shortcomings of this study is that hyposmia is not questioned adequately. Constipation, from nonmotor findings, is an autonomic finding of IPD and can be seen before or after diagnosis. Considering the most commonly used criterion of frequency, (i.e., $<3$ bowel movements per week), the median 
prevalence of constipation in PD was found to be $50 \%$ with a range varying from 20 to 63 . Prevalence of straining generally exceeded prevalence of decreased frequency of bowel movements, showing also variation across various studies $(33 \%-83 \%)^{23}$. Different prevalence rates were also found between patients with

akinetic-rigid form and tremor-dominant phenotype: $64 \%$ vs $49 \%$ in advanced parkinsonian patients, and $45 \%$ vs $21 \%$ in a study on de novo PD patients ${ }^{24,25}$. Constipation was detected in $36.2 \%$ of the patients in our study group, and this rate was slightly higher in women. As compared with the literature, the lower rate of constipation can be explained by the high rate of apricot production and consumption in our region.

The incidence of cognitive impairment in patients with Parkinson's is markedly high. A Canadian review published in 2016 highlighted the high risk of dementia in IPD. In the same review, it was emphasized that the risk in early-stage Parkinson's patients was $20 \%-40 \%$, whereas in advanced stage (20 years after diagnosis), the risk increased to $80 \%{ }^{26}$. In another prospective, longitudinal, 12 -year cohort study, it was noted that $60 \%$ of patients developed dementia, and the cumulative incidence increased in proportion to patient age and duration of the disease and peaked at $80 \%-90 \%$ when one reaches 90 years old; the dementia rate increased in later stages of the disease ${ }^{27}$. In our study, the rate of dementia in H\&Y Stage 1 and 5 was $25 \%$ and $75 \%$, respectively. In other words, in accordance with the literature, it is evident that the risk of dementia increases as the clinical stage progresses.

We included DSE, ICBs, on-off and wearing-off phenomena, dystonia, and dyskinesias as problems related to treatment. DSE was seen in $45.2 \%$ of the patients. These side effects are nonspecific symptoms such as nausea, vomiting, hypotension, hot flashes and dizziness, especially seen in the first days of treatment. Dyskinesia from motor fluctuations were noted in 26\%; wearing-off phenomena were seen in $14.5 \%$; on-off phenomena were observed 15.4\%; and dystonia was noted in $5.9 \%$. In another series of 301 patients in the United States in 2004, an increase in the frequency of wearing-off phenomena was shown with an increase in LD dose ${ }^{28}$. ICBs was detected in $10.7 \%$ of our patients. Around 63\% (n: 366) of our patients used dopamine agonist and 84\% (n: 488) used levodopa as a combination or monotherapy. ICBs was significantly higher in males and in patients receiving pramipexole. This finding was seen in 48 men but only in 14 women. In a study conducted in Mexico in 2014, ICBs was seen more frequently in pramipexole users than patients using other medications ${ }^{29}$. Conditions that increase the risk of impulsive compulsive behavior are as follows: diagnosis age $<45$, duration of disease $>5$ years, impulsive character traits, being involved in self-risk activities, ICBs or punding, substance or alcohol use, and history of depression and insomnia ${ }^{7-30}$. In our study, ICBs was found to be higher in males, which is in accordance with the literature. This has shown that before starting dopamine agonist in young male patients, it may be necessary to deepen anamnesis, to have knowledge about personality traits, and to seek psychiatrist opinion.

In conclusion, in this study conducted in our region, many variables such as epidemiological findings, demographic characteristics, clinical symptoms, and treatment problems were found to be similar to the general world. When evaluating the results, we found that we missed the evaluation of some findings under routine intensive polyclinic conditions and lost the chance of treatment because we did not ask about the problems that the patient did not rise. Therefore, the result of this study was to realize our shortcomings and the possibility of correction.

Ethics Committee Approval: The study was approved by the Inonu Medical Faculty Ethics Committee. Ethics committee approval was obtained for this protocol 2017/13-15 on $20 / 06 / 2017$. Informed consent was obtained. The study complied with the Declaration of Helsinki.

Declaration of Conflicting Interests: The authors declare that they have no conflict of interest.

Financial Disclosure: No financial support was received.

\section{REFERENCES}

1. Bekris LM, Mata IF, Zabetian CP. The Genetics of Parkinson Disease, Journal of Geriatric Psychiatry and Neurology. 2010; 23: 228-42. 
2. Arikanoglu A, Hunkar R, Cinar K. Parkinsonism secondary to bilateral subdural hematoma. Dicle Med J. 2011; 38: 247-9.

3. Kalia LV, Lang AE. Parkinson disease in 2015: Evolving basic, pathological and clinical concepts in PD. Nat Rev Neurol. 2016; 12: 65-6.

4. Gaare JJ, Skeie GO, Tzoulis C, Larsen JP, Tysnes OB. Familial aggregation of Parkinson's disease may affect progression of motor symptoms and dementia. Movement disorders: official Journal of the Movement Disorder Society. 2017; 32: 241-45.

5. Breckenridge CB, Berry C, Chang ET, Sielken Jr RL, Mandel JS. Association between Parkinson's Disease and Cigarette Smoking, Rural Living, Well-Water Consumption, Farming and Pesticide Use: Systematic Review and Meta-Analysis. PloS one. 2016; 11: e0151841.

6. Ritz B, Lee PC, Lassen CF, Arah OA. Parkinson disease and smoking revisited: ease of quitting is an early sign of the disease. Neurology. 2014; 83: 1396-402.

7. PD MED Collaborative Group. Long-term eff ectiveness of dopamine agonists and monoamine oxidase B inhibitors compared with levodopa as initial treatment for Parkinson's disease (PD MED): a large, open-label, pragmatic randomised trial. Lancet. 2014; 384: 1196205.

8. Martin I, Dawson VL, Dawson TM. Recent advances in the genetics of Parkinson's disease. Annu Rev Genomics Hum Genet. 2011; 12: 301-25.

9. Driver JA, Logroscino G, Gaziano JM, Kurth T. Incidence and remaining lifetime risk of Parkinson disease in advanced age. Neurology. 2009; 72: 432-8.

10. Pringsheim T, Jette N, Frolkis A, Steeves TDL. The prevalence of Parkinson's disease: a systematic review and meta-analysis. Mov Disord. 2014; 29: 1583-90.

11. Benito-León J1, Bermejo-Pareja F, Rodríguez J, et al. Prevalence of PD and other types of parkinsonism in three elderly populations of central Spain Neurological Disorders in Central Spain (NEDICES) Study Group. Mov disord. 2003; 18: 267-74.

12. Picillo M, Nicoletti A, Fetoni $V$, et al. The relevance of gender in Parkinson's disease: a review. J Neurol. 2017 Aug; 264(8): 1583-1607. doi: 10.1007/s00415-0168384-9. Epub 2017 Jan 4.

13. Noyce AJ, Bestwick JP, Silveira-Moriyama L, et al. Meta-analysis of early nonmotor features and risk factors for Parkinson disease. Ann Neurol. 2012; 72: 893-901.

14. Belvisi D, Conte A, Bologna $\mathrm{M}$, et al. Re-emergent tremor in Parkinson's disease, Parkinsonism Relat
Disord. 2016; 36: 41-46.

http://dx.doi.org/10.1016/j.parkreldis. 2016.12.012.

15. Martin WE, Loewenson RB, Resch JA, Baker AB. Parkinson's disease: clinical analysis of 100 patients. Neurology. 1983; 23: 783-90.

16. Beiske AG, Loge JH, Rønningen A, Svensson E. Pain in Parkinson's disease: Prevalence and characteristics. Pain. 2009; 141: 173-7. doi: 10.1016/j.pain.2008.12.004.

17. Hanagasi HA, Akat S, Gurvit H, Yazici J, Emre M. Pain is common in Parkinson's disease. Clinical Neurology and Neurosurgery Clin Neurol Neurosurg. 2011 Jan; 113: 1113. doi: 10.1016/j.clineuro.2010.07.024.

18. Yoritaka A, Ohizumi H, Tanaka S, Hattori N. Parkinson's disease with and without REM sleep behaviour disorder: are there any clinical differences? Eur Neurol. 2009; 61: 164-70.

19. Howell MJ, Schenck CH. Rapid eye movement sleep behavior disorder and neurodegenerative disease. JAMA Neurol. 2015; 72: 707-12.

20. Doty RL. Olfaction in Parkinson's disease and related disorders. Neurobiol Dis. 2012; 46: 527-52.

21. Postuma RB, Gagnon JF, Vendette M, Desjardins C, Montplaisir JY. Olfaction and color vision identify impending neurodegeneration in rapid eye movement sleep behavior disorder. Ann Neurol 2011; 69: 811-8.

22. Altinayar S, Oner S, Can S, Kizilay A, Kamisli S, Sarac K. Olfactory disfunction and its relation olfactory bulb volume in Parkinson's disease. Eur Rev Med Pharmacol Sci. 2014; 18: 3659-64.

23. Knudsen K, Krogh K, Østergaard K, Borghammer P. Constipation in Parkinson's disease: Subjective symptoms, objective markers, and new perspectives. Movement Disorders. 2017; 32: 94-105.

24. Khedr EM, Fetoh El NA, Khalifa H, Ahmed MA, Beh El KM. Prevalence of non-motor features in a cohort of Parkinson's disease patients. Clinical Neurology and Neurosurgery. 2013; 115: 673-7.

25. Pont-Sunyer C, Hotter A, Gaig C, et al. The onset of nonmotor symptoms in Parkinson's disease (the ONSET PD study). Movement Disorders. 2015; 30: 229-37.

26. Monchi O, Hanganu A, Bellec P. Markers of cognitive decline in PD: The case for heterogeneity. Parkinsonism \& Related Disorders. 2016; 24: 8-14.

27. Buter TC, van den Hout A, Matthews FE, et al. Dementia and survival in Parkinson disease: a 12-year population study. Neurology. 2008; 70: 1017-22.

28. Parkinson Study Group. Pramipexole vs levodopa as initial treatment for Parkinson disease: a 4-year 
randomized controlled trial. Archives of Neurology. 2004; 61: 1044-53.

29. Violante MR, Latapi PG, Arriaga AC, Ordonez AC, Weintraub D. Impulse control and related disorders in Mexican Parkinson's disease patients. Parkinsonism and Related Disorders. 2014; 20: 907-10.
30. Cilia R, Siri C, Canesi M, et al. Dopamine dysregulation syndrome in Parkinson's disease: from clinical and neuropsychological characterisation to management and long-term outcome. J Neurol Neurosurg Psychiatry. 2014; 85: 311-8. 